\title{
Rapid Sand Filter
}

Oleh Gede H. Cahyana

Lektor Kepala Teknik Lingkungan Universitas Kebangsaan

Majalah Air Minum Edisi 312, September 2021

Benteng pengolahan air adalah filter. Bahkan IPAM disebut instalasi filtrasi. Filter dapat menghasilkan air yang sangat jernih apalagi kalau dilengkapi dengan unit koagulasi, flokulasi dan sedimentasi. Selain kekeruhan, filter mampu menyisihkan bakteri, protozoa, mesozoa. Virus pun, khususnya oleh slow sand filter (SSF, filter pasir lambat) dapat disisihkan karena memiliki lapisan biologi (biolapis) yang disebut Schmutzdecke. Biolapis ini disebut juga dirt layer, filter skin, filter cake, biological layer.

Artikel tentang slow sand filter sudah dimuat di MAM edisi 149, Februari 2008 dan operasi rawatnya dimuat pada edisi 174, Maret 2010. Kali ini dibahas rapid sand filter (RSF, filter pasir cepat). Merujuk pada buku Drinking Water karya de Moel, Verberk, van Dijk (2006), diterbitkan oleh TU Delft, the Netherlands dan World Scientific Publishing, filter pasir cepat pertama kali dibuat di Amerika Serikat pada tahun 1885 dan di Eropa pada tahun 1895.

\section{Media filter}

Jantung pengolahan air pada filter adalah medianya (filter bed). Di dalam media inilah terjadi penyisihan kekeruhan dan mikroba. Mekanisme yang terjadi di dalam media RSF adalah straining, sedimentasi, flokulasi, difusi, inersia, intersepsi, hidrodinamika. Semua mekanisme ini terjadi di dalam rongga mikro atau parasitas (perviousness), yaitu rasio volume rongga di dalam media filter terhadap volume kosong bak filter. Parasitas berbeda dengan porositas (porosity). Porositas adalah rongga di dalam butiran media bukan rongga antara butir-butir media filter.

Media yang biasa digunakan adalah pasir kwarsa. Media lainnya adalah antrasit, magnetit, garnet, dan media sintetis. Jenis media memiliki karakteristik khas yang mempengaruhi kinerja filter dalam penyisihan kekeruhan dan mikroba. Juga berpengaruh pada kinerja hidrolisnya. Khusus untuk pasir, parameter yang penting adalah karakteristik fisika: ukuran, bentuk, kekerasan, kemurnian. Ukuran berkaitan dengan ukuran efektif (effective size), biasanya 0,45 mm dan koefisien keseragaman (uniformity coefficient), biasanya 1,5. Bentuknya ada yang bundar, menyudut, tajam, dan campuran. Media filter harus keras (kuat) agar tidak mudah hancur. Kemurnian artinya bersih dari kotoran (lempung, zat organik).

Karakteristik kimia pasir adalah $\mathrm{Na}_{2} \mathrm{O}, \mathrm{K} 2 \mathrm{O}, \mathrm{CaO}, \mathrm{MgO}, \mathrm{Fe}_{2} \mathrm{O}_{3}, \mathrm{Al}_{2} \mathrm{O}_{3}$, dan $\mathrm{SiO}_{2}$. Senyawa yang utama adalah $\mathrm{SiO} 2$ atau silika. Persentase silika harus tinggi, lebih dari 98\%. Silika menentukan kekerasan pasir sehingga tidak mudah pecah selama pencucian media filter dengan aliran balik akibat saling tabrak antara butir-butir pasir. Apabila getas maka pasir akan mudah pecah dan filter justru makin cepat tersumbat. Parameter kimia lainnya adalah konsentrasi zat organik, ion besi, mangan, dan ketahanannya terhadap kondisi asam ( $\mathrm{pH}$ rendah). Kondisi asam bisa terjadi karena proses penglahan air menggunakan alum sulfat.

Parameter selanjutnya adalah luas permukaan media, bukan luas permukaan bak filter. Luas permukaan media yang dihasilkan oleh satu satuan volume media filter, sangat besar. Satu meter kubik pasir berdiameter $0,5 \mathrm{~mm}$ dengan parasitas 0,4 berisi kurang lebih $9,17 \times 10^{9}$ butir pasir. 
Lebih dari sembilan miliar butir pasir. Adapun luas total permukaan pasir sekitar $7,2 \times 10^{3} \mathrm{~m}^{2}$ per $\mathrm{m}^{3}$ pasir. Luas permukaan efektifnya diasumsikan $1 \%$ atau $72 \mathrm{~m}^{2}$ per $\mathrm{m}^{3}$ pasir. Di atas "bidang" seluas itulah terjadi fenomena flokulasi, sedimentasi, straining, difusi laminar turbulen, inersia, intersepsi, hidrodinamika.

\section{Desain filter}

Sesuai dengan namanya, kecepatan air di dalam RSF antara $2-5 \mathrm{~mm} /$ detik atau $7-18 \mathrm{~m} / \mathrm{jam}$. Di Indonesia kecepatan rerata yang digunakan adalah $5 \mathrm{~m} / \mathrm{jam}$, setara dengan 1,37 liter per detik per meter persegi luas permukaan filter atau $2 \mathrm{gpm} / \mathrm{ft}^{2}$ (gallon per minute/square feet). Hal penting lainnya adalah debit, yaitu volume air yang diolah per satuan waktu. Disebut juga besaran sistem dengan satuan $\mathrm{m}^{3} /$ detik atau liter/detik. Dengan data kecepatan filtrasi dan debit air yang diolah tersebut maka dapat dihitung luas filter yang dibutuhkan. Juga bisa dihitung banyaknya filter dan cadangannya yang harus dibuat. Apabila semua filter dan cadangannya diketahui jumlahnya maka bisa digambar layout filter.

Berdasarkan data luas permukaan bak filter maka bisa dihitung desain sistem underdrain, yaitu sistem yang menyalurkan air filtrat menuju clear well atau reservoir. Sistem underdrain atau drainase (bawah) juga berfungsi meratakan aliran air pencuci ke seluruh bagian media. Makna meratakan ini adalah rata debitnya dan rata kecepatannya. Apabila salah satunya tidak terpenuhi maka proses pembersihan sludge (clogging) tidak akan optimal. Satu bagian mungkin bersih tetapi bagian lainnya masih tersumbat. Bisa juga pasir-pasir halusnya hanyut terbuang bersama aliran air pencuci. Akibatnya kinerja filter menurun, cepat clogging, kualitas filtrat memburuk sehingga reservoir menjadi kotor karena endapan sludge. Sekali waktu endapan ini resuspensi sehingga air yang didistribusikan ke pelanggan menjadi keruh.

Sistem drainase filter seperti kaki manusia. Ketimpangan sistem drainase bisa melumpuhkan operasi filter dan memperburuk kualitas air olahan. Sistem drainase bisa menggunakan jaringan pipa berlubang (perforated pipe) yang ditutupi kerikil. Jaringan pipa perforasi ini seperti tulang ikan, ada pipa besar yang disebut manifold dan pipa lateral yang tegak lurus manifold. Lubang atau orifice hanya dibuat di bagian bawah dinding pipa lateral. Posisi di bawah dapat mencegah butir-butir pasir, apabila terjadi karena sebab tertentu, masuk ke dalam pipa. Sistem lainnya adalah menggunakan false floor (bottom) yang dilengkapi nozzle. Kelengkapan lain sistem drainase filter adalah katup, alat kontrol aliran dan kecepatan untuk mengatur tinggi muka air di filter, laju filtrasi, dan laju air pencuci agar sesuai dengan desainnya.

\section{Backwashing}

Setelah beroperasi sekian jam atau hari, bergantung pada kekeruhan air dan debitnya, maka RSF tersumbat. Kinerja filter menurun, debit berkurang dan kualitas filtrat memburuk. Sumbatan mikoflok di media pasir harus segera dibersihkan. Menurut sejarahnya, awalnya pembersihan filter dilakukan secara manual dengan tangan, dibersihkan dari atas bak filter menggunakan batang logam bercabang-cabang. Alat ini dimasukkan ke lapisan atas filter, digerak-gerakkan sehingga sludge terlepas. Selanjutnya air yang sangat keruh ini dibuang lewat lubang atau gutter (talang) di dinding filter.

Pencucian manual tentu tidak efektif untuk kapasitas besar. Lantas berkembang teknologi yang lebih praktis dengan cara mengalirkan air dari arah berlawanan dengan arah filtrasi yang disebut 
backwashing menggunakan air filtrat. Aliran balik ini mengaduk lapisan pasir bagian atas sehingga terekspansi. Sumbatan bisa terbuka kemudian flok (sludge) terlepas dari pasir. Agar lekatan flok lebih mudah hanyut terbawa air pencuci maka filter dilengkapi dengan air scouring (gesekan udara). Air scouring ini dilaksanakan lebih dulu kemudian disusul oleh backwashing dengan air bersih dari reservoir atau menara air (elevated tank).

Cara lainnya ialah menggunakan air dan semprotan permukaan (surface jets). Bisa juga dengan udara (air scouring) dan air bersamaan kemudian dibilas lagi dengan air. Semua cara tersebut membutuhkan kecepatan aliran ke atas yang berbeda dan ekspansi yang terjadi juga berbeda. Ekspansi lapisan pasir bagian atas selama backwashing menghasilkan parasitas 1,5 kali parasitas media pasir. Kecepatan air pencucinya adalah tujuh kali kecepatan filtrasi. Apabila kecepatan filtrasi $1,37 \mathrm{l} / \mathrm{d}$ per $\mathrm{m}^{2}$ luas filter maka kecepatan air pencuci $10 \mathrm{l} / \mathrm{d} \mathrm{per} \mathrm{m}^{2}$ atau $1 \mathrm{~cm} /$ detik. Kecepatan air pencuci tidak boleh melebihi kecepatan pengendapan pasir terkecil agar pasir tidak hanyut. Kecepatan air pencuci sekadar dapat merenggangkan jarak antarpasir saja.

Ada satu lagi parameter penting di dalam RSF, yaitu elevasi gutter atau talang penyalur air cucian. Elevasi gutter harus tepat dan sesuai dengan kecepatan air pencucinya. Praktiknya relatif sulit sehingga pasir selalu saja ada yang terbuang. Secara berkala pasir filter perlu ditambah seberat pasir yang hilang dan sama diameternya. [] 


\section{Rapid Sand Filter}

Benteng pengolahan air adalah filter. Bahkan, IPAM disebut instalasi filtrasi. Filter dapat menghasilkan air yang sangat jernih, apalagi kalau dilengkapi dengan unit koagulasi, flokulasi dan sedimentasi. Selain kekeruhan, filter mampu menyisihkan bakteri, protozoa, dan mesozoa. Virus pun, khususnya oleh slow sand filter (SSF, filter pasir lambat), dapat disisihkan karena memiliki

lapisan biologi (biolapis) yang disebut Schmutzdecke. Biolapis ini disebut juga dirt layer, filter skin, filter cake, dan biological layer.

\footnotetext{
A rtikel tentang slow sand filter sudah dimuat di MAM edisi 149, Februari 2008 dan operasi rawatnya dimuat pada edisi 174 , Maret 2010. Kali ini dibahas rapid sand filter (RSF, filter pasir cepat). Merujuk pada buku Drinking Water karya de Moel, Verberk, van Dijk (2006), diterbitkan oleh TU Delft, the Netherlands dan World Scientific Publishing, filter pasir cepat pertama kali dibuat di Amerika Serikat pada tahun 1885 dan di Eropa pada tahun 1895.

Media filter

Jantung pengolahan air pada filter adalah medianya (filter bed). Di dalam media inilah terjadi penyisihan kekeruhan dan mikroba. Mekanisme yang terjadi di dalam media RSF adalah straining, sedimentasi, flokulasi, difusi, inersia,
}

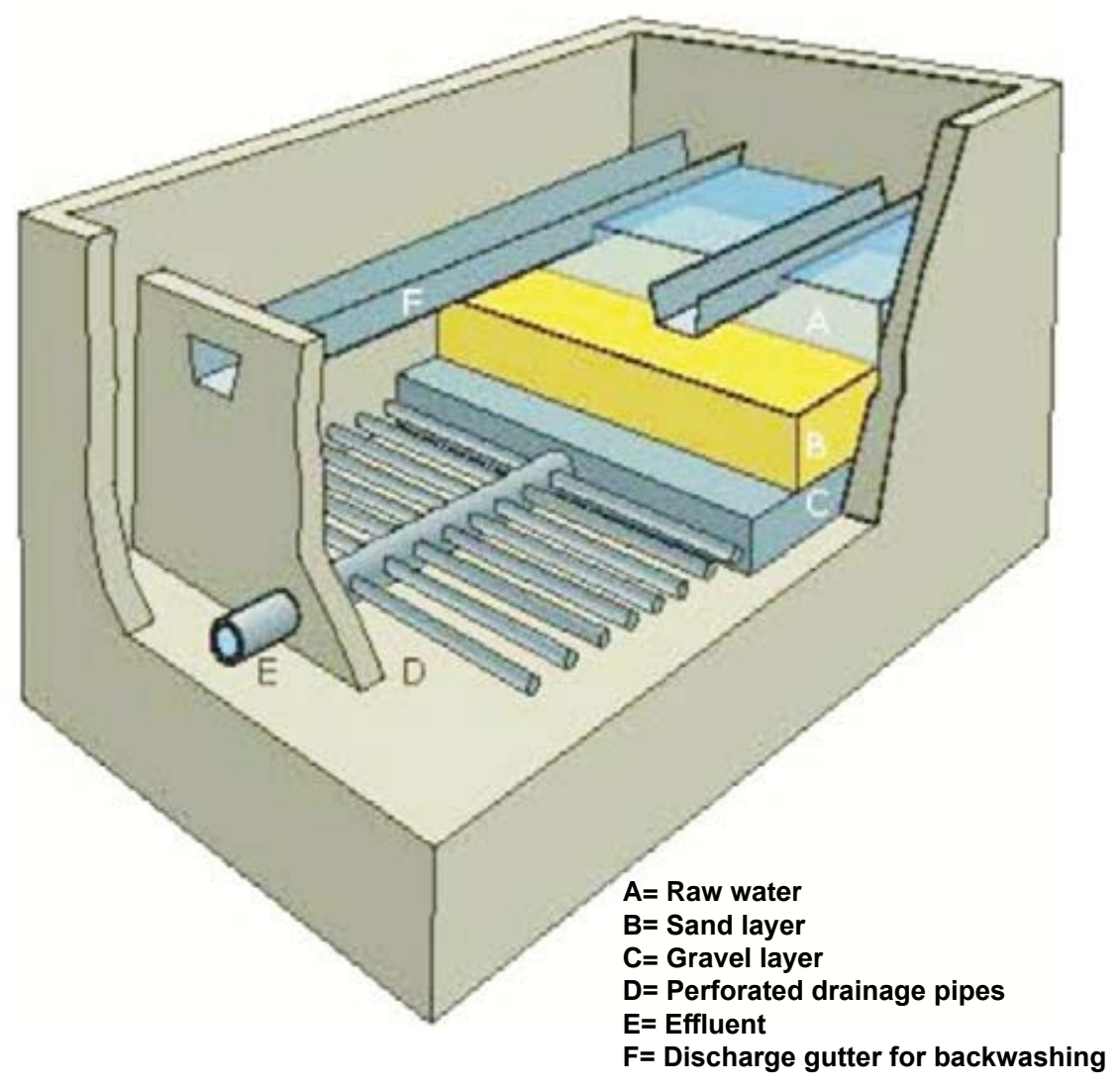

intersepsi, dan hidrodinamika. Semua mekanisme ini terjadi di dalam rongga mikro atau parasitas (perviousness), yaitu rasio volume rongga di dalam media filter terhadap volume kosong bak filter. Parasitas berbeda dengan porositas (porosity). Porositas adalah rongga di dalam butiran media bukan rongga antara butir-butir media filter.

Media yang biasa digunakan adalah pasir kwarsa. Media lainnya adalah antrasit, magnetit, garnet, dan media sintetis. Jenis media memiliki karakteristik khas yang memengaruhi kinerja filter dalam penyisihan kekeruhan dan mikroba. Ini juga berpengaruh pada kinerja hidrolisnya. Khusus untuk pasir, parameter yang penting adalah karakteristik fisika: ukuran, bentuk, kekerasan, dan kemurnian. Ukuran berkaitan dengan ukuran efektif (effective size), biasanya 0,45 $\mathrm{mm}$ dan koefisien keseragaman (uniformity coefficient), biasanya 1,5 . Bentuknya ada yang bundar, menyudut, tajam, dan campuran. Media filter harus keras (kuat) agar tidak mudah hancur. Kemurnian artinya bersih dari kotoran (lempung, zat organik).

Karakteristik kimia pasir adalah $\mathrm{Na}_{2} \mathrm{O}, \mathrm{K}_{2} \mathrm{O}, \mathrm{CaO}, \mathrm{MgO}, \mathrm{Fe}_{2} \mathrm{O}_{3}, \mathrm{Al}_{2} \mathrm{O}_{3}$, dan $\mathrm{SiO}_{2}$. Senyawa yang utama adalah SiO2 atau silika. Persentase silika harus tinggi, lebih dari $98 \%$. Silika menentukan kekerasan pasir sehingga tidak mudah pecah selama pencucian media filter dengan aliran balik akibat saling tabrak antara butir-butir pasir. Kalau getas, pasir akan mudah pecah dan filter justru makin cepat tersumbat. Parameter kimia lainnya adalah konsentrasi zat organik, ion besi, mangan, dan ketahanannya pada kondisi asam ( $\mathrm{pH}$ rendah). Kondisi asam bisa 
terjadi karena proses pengolahan air menggunakan alum sulfat.

Parameter selanjutnya adalah luas permukaan media, bukan luas permukaan bak filter. Luas permukaan media yang dihasilkan oleh satu satuan volume media filter sangat besar. Satu meter kubik pasir berdiameter $0,5 \mathrm{~mm}$ dengan parasitas 0,4 berisi kurang lebih 9,17 $\times 10^{9}$ butir pasir. Lebih dari sembilan miliar butir pasir. Adapun luas total permukaan pasir sekitar 7,2 x 10 3 $\mathrm{m}^{2}$ per $\mathrm{m}^{3}$ pasir. Luas permukaan efektifnya diasumsikan $1 \%$ atau 72 $\mathrm{m}^{2}$ per $\mathrm{m}^{3}$ pasir. Di atas "bidang" seluas itulah terjadi fenomena flokulasi, sedimentasi, straining, difusi laminar - turbulen, inersia, intersepsi, dan hidrodinamika.

\section{Desain filter}

Sesuai dengan namanya, kecepatan air di dalam RSF antara 2-5 mm/detik atau 7-18 m/jam. Di Indonesia kecepatan rerata yang digunakan adalah $5 \mathrm{~m} / \mathrm{jam}$, setara dengan 1,37 liter per detik per meter persegi luas permukaan filter atau $2 \mathrm{gpm} / \mathrm{ft}^{2}$ (gallon per minute/square feet). Hal penting lainnya adalah debit, yaitu volume air yang diolah per satuan waktu. Disebut juga besaran sistem dengan satuan $\mathrm{m}^{3} /$ detik atau liter/detik. Dengan data kecepatan filtrasi dan debit air yang diolah tersebut maka dapat dihitung luas filter yang dibutuhkan. Juga bisa dihitung banyaknya filter dan cadangannya yang harus dibuat. Apabila semua filter dan cadangannya diketahui jumlahnya, maka bisa digambar layout filter.

Berdasarkan data luas permukaan bak filter, maka bisa dihitung desain sistem underdrain, yaitu sistem yang menyalurkan air filtrat menuju clear well atau reservoir. Sistem underdrain atau drainase (bawah) juga berfungsi meratakan aliran air pencuci ke seluruh bagian media. Makna meratakan ini adalah rata debitnya dan rata kecepatannya. Apabila salah satunya tidak terpenuhi, maka proses pembersihan sludge (clogging) tidak akan optimal. Satu bagian mungkin bersih tetapi bagian lainnya masih tersumbat. Bisa juga pasir-pasir halusnya hanyut terbuang bersama aliran air pencuci. Akibatnya, kinerja filter menurun, cepat clogging, kualitas filtrat memburuk sehingga reservoir menjadi kotor karena endapan sludge. Sekali waktu, endapan ini resuspensi. Sehingga, air yang didistribusikan ke pelanggan menjadi keruh.

Sistem drainase filter seperti kaki manusia. Ketimpangan sistem drainase bisa melumpuhkan operasi filter dan memperburuk kualitas air olahan. Sistem drainase bisa menggunakan jaringan pipa berlubang (perforated pipe) yang ditutupi kerikil. Jaringan pipa perforasi ini seperti tulang ikan, ada pipa besar yang disebut manifold dan pipa lateral yang tegak lurus manifold. Lubang atau orifice hanya dibuat di bagian bawah dinding pipa lateral. Posisi di bawah dapat mencegah butir-butir pasir, apabila terjadi karena sebab tertentu, masuk ke dalam pipa. Sistem lainnya adalah menggunakan false floor (bottom) yang dilengkapi nozzle. Kelengkapan lain sistem drainase filter adalah katup, alat kontrol aliran dan kecepatan untuk mengatur tinggi muka air di filter, laju filtrasi, dan laju air pencuci agar sesuai dengan desainnya.

\section{Backwashing}

Setelah beroperasi sekian jam atau hari, bergantung pada kekeruhan air dan debitnya, maka RSF tersumbat. Kinerja filter menurun, debit berkurang dan kualitas filtrat memburuk. Sumbatan mikroflok di media pasir harus segera dibersihkan. Menurut sejarahnya, awalnya pembersihan filter dilakukan secara manual dengan tangan, dibersihkan dari atas bak filter menggunakan batang logam bercabang-cabang. Alat ini dimasukkan ke lapisan atas filter, digerak-gerakkan sehingga sludge terlepas. Selanjutnya, air yang sangat keruh ini dibuang lewat lubang atau gutter (talang) di dinding filter.

Pencucian manual tentu tidak efektif untuk kapasitas besar. Lantas berkembang teknologi yang lebih praktis dengan cara mengalirkan air dari arah berlawanan dengan arah filtrasi yang disebut backwashing menggunakan air filtrat. Aliran balik ini mengaduk lapisan pasir bagian atas sehingga terekspansi. Sumbatan bisa terbuka kemudian flok (sludge) terlepas dari pasir. Agar lekatan flok lebih mudah hanyut terbawa air pencuci maka filter dilengkapi dengan air scouring (gesekan udara). Air scouring ini dilaksanakan lebih dulu kemudian disusul oleh backwashing dengan air bersih dari reservoir atau menara air (elevated tank).

Cara lainnya ialah menggunakan air dan semprotan permukaan (surface jets). Bisa juga dengan udara (air scouring) dan air bersamaan kemudian dibilas lagi dengan air. Semua cara tersebut membutuhkan kecepatan aliran ke atas yang berbeda dan ekspansi yang terjadi juga berbeda. Ekspansi lapisan pasir bagian atas selama backwashing menghasilkan parasitas 1,5 kali parasitas media pasir. Kecepatan air pencucinya adalah tujuh kali kecepatan filtrasi. Apabila kecepatan filtrasi 1,37 l/d per $\mathrm{m}^{2}$ luas filter, maka kecepatan air pencuci $10 \mathrm{l} / \mathrm{d}$ per $\mathrm{m}^{2}$ atau $1 \mathrm{~cm} /$ detik. Kecepatan air pencuci tidak boleh melebihi kecepatan pengendapan pasir terkecil agar pasir tidak hanyut. Kecepatan air pencuci sekadar dapat merenggangkan jarak antarpasir saja.

Ada satu lagi parameter penting di dalam RSF, yaitu elevasi gutter atau talang penyalur air cucian. Elevasi gutter harus tepat dan sesuai dengan kecepatan air pencucinya. Praktiknya relatif sulit sehingga pasir selalu saja ada yang terbuang. Secara berkala pasir filter perlu ditambah seberat pasir yang hilang dan sama diameternya. E

Gede H. Cahyana

Lektor Kepala Teknik Lingkungan Universitas Kebangsaan 